\title{
PERLINDUNGAN HUKUM BAGI PASIEN TERHADAP MALPRAKTEK PADA PENGOBATAN TRADISIONAL
}

\author{
Syifa Alam \\ syifaalam1992@gmail.com \\ Universitas Airlangga
}

\begin{abstract}
Healthy treatment with medical method or traditional method are a form of health services by health workers. Based on article 11 paragraph (1) Law number 36 year 2014 concerning Health Worker stated that Traditional Healer is categorized as a Health Worker. Since there are so many people that interest with traditional treatment, the government provides regulations and provides practice health services permits related to operate traditional treatment as a form of legal protection for users of health services. In order to provide traditional treatment practice permit it is required to obtain the recommendation from association of traditional treatment. When Traditional Healer conducts health service, he needs to comply with the procedurs in professional standard, health services standard and procedurs standard that have been determinded by the association of traditional treatment. In practice of traditional treatment there is civil relation between traditional healer and patient. Traditional healers in performing health services for patients can make mistakes or defaults that cause a decreased health for the patients. This condition will harm the patients, therefore there should be a form of legal protection for patients so that patients can claim their rights in order to create a legal certainty in health services, especially traditional treatment. The regulation of legal protection in civil form is not regulated in details in Law number 36 year 2009 concerning Health, so that it is required to further study the form of legal protection for the patients refer to Burgerlijk Wetboek, Law number 8 of 1999 concerning Consumer Protection along with an analyze of a case regarding a traditional treatment patient who is harmed upon health service provided by traditional healer.
\end{abstract}

Keywords: Traditional Treatment; Patients; Legal Protection.

\begin{abstract}
Abstrak
Pengobatan dengan cara medis maupun dengan cara tradisional merupakan bentuk dari pelayanan kesehatan oleh tenaga kesehatan. Berdasarkan Pasal 11 ayat (1) Undang-Undang 36 Tahun 2014 tentang Tenaga Kesehatan, Pengobat Tradisional dikategorikan sebagai Tenaga Kesehatan. Dikarenakan banyaknya masyarakat peminat pengobatan tradisional, pemerintah memberikan peraturan maupun izin praktik terkait pelayanan kesehatan dalam bentuk pengobatan taradisional sebagai bentuk perlindungan hukum kepada pengguna jasa pelayanan kesehatan. Dalam Pemberian izin praktik pengobatan tradisional diperlukan rekomendasi dari asosiasi pengobatan tradisional. Pengobat tradisional dalam melakukan pelayanan kesehatan harus mematuhi ketentuan-ketentuan dalam standar profesi, standar pelayanan kesehatan dan standar prosedur yang sudah ditentukan. Dalam praktik pengobatan tradisional terdapat hubungan keperdataan antara pengobat tradisional dengan Pasien. Pengobat tradisional dalam melakukan pelayanan kesehatan kepada pasien bisa saja melakukan kesalahan atau kelalaian yang menyebabkan kemunduran kesehatan pada pasien. Hal tersebut merugikan pasien, oleh sebab itu harus adanya bentuk perlindungan hukum bagi pasien sehingga pasien dapat menuntut haknya agar terciptanya kepastian hukum atas pelayanan kesehatan khususnya pengobatan tradisional. Pengaturan mengenai bentuk perlindungan hukum secara perdata tidak secara detail diatur dalam Undang-undang nomor 36 tahun 2009 tentang Kesehatan, sehingga perlu dilakukan pengkajian atas bentuk upaya hukum tersebut berdasarkan Burgerlijk Wetboek, Undang-undang nomor 8 tahun 1999 mengenai Perlindungan Konsumen beserta dengan analisis atas suatu kasus pasien pengobat tradisional yang dirugikan atas pelayanan pengobat tradisional.
\end{abstract}

Kata Kunci: Pengobatan Tradisional; Pasien; Perlindungan hukum. 


\section{Pendahuluan}

Pembangunan di bidang kesehatan pada dasarnya ditujukan untuk membangun kesadaran dan kemauan hidup sehat demi terciptanya derajat kesehatan yang optimal bagi setiap masyarakat sebagai wujud peningkatan kesejahtraan sesuai dengan amanat Undang-Undang Dasar Negara Republik Indonesia Tahun 1945. Di dalam Pasal 28H ayat (1) Undang-Undang Dasar 1945 dijelaskan bahwa: "setiap orang berhak hidup sejahtera lahir dan batin, bertempat tinggal, dan mendapat lingkungan yang baik dan sehat serta memperoleh pelayanan kesehatan". Pasal tersebut merupakan hak yang paling mendasar karena di dalamnya terkandung pengertian tentang Hak Asasi Manusia (HAM) yang bersifat mutlak. Di dalam Pasal tersebut terkandung hak bagi manusia memperoleh pelayanan kesehatan. Pengaturan secara spesifik terkait kesehatan terdapat dalam Undang-Undang Kesehatan, Peraturan Pemerintah mauppun Peraturan Menteri Kesehatan dimana di dalamnya mengatur berbagai aspek mengenai kesehatan.

Kesehatan merupakan salah satu kebutuhan pokok manusia selain sandang, pangan, papan. Persoalan kesehatan merupakan masalah esensial bagi setiap negara, baik itu negara maju, maupun negara berkembang. Kemajuan teknologi sangat mempengaruhi perkembangan bidang kesehatan, penyakit-penyakit yang dahulu belum ditemukan obatnya, saat ini sudah bisa ditemukan obatnya akibat kemajuan teknologi, namun terdapat juga penyakit yang sampai saat ini belum bisa ditemukan obatnya maupun cara penyembuhannya.

Walaupun kemajuan teknologi dan ilmu pengetahuan sudah sedimikian majunya, namun tidak dapat dipungkiri masyarakat Indonesia masih memberikan kepercayaan kepada praktik pengobatan tradisional seperti pijat, totok, dan jenis praktik pengobatan tradisional lainnya disamping praktik Pengobatan medis resmi dalam memenuhi kebutuhan kesehatannya. Langkah Pengobatan Tradisional tersebut sebagai langkah preventif maupun langkah represif menghadapi suatu penyakit walaupun kemajuan teknologi di bidang kedokteran sudah sedemikian majunya. Keadaan tersebut diperkuat dengan adanya beberapa kasus pengobatan tradisional yang mampu menyembuhkan penyakit yang sebelumnya gagal ditangani oleh ilmu kedokteran. 
Persoalan lain yang menyebabkan eksistensi pengobatan tradisional masih dipercaya masyarakat adalah disebabkan oleh akses akan pelayanan kesehatan resmi yang berdasarkan standar kedokteran tidak secara merata bisa dinikmati oleh setiap orang, sehingga sering kali pengobatan tradisional merupakan pilihan bagi mereka yang memiliki kemampuan ekonomi terbatas guna memenuhi kebutuhan kesehatannya, sehingga pengobatan tradisional merupakan unsur pelengkap bagi masyarakat dalam pelayanan kesehatan disamping pengobatan modern.

Keberadaan pengobatan tradisional yang sekarang ini merupakan bukti sejarah dari upaya pelayanan kesehatan pada masa lalu, dimana pada masa lalu pelayanan kesehatan pada masih menggunakan alat-alat tradisional maupun ramuan tradisional Walaupun kemajuan teknologi dan ilmu pengetahuan sudah sedimikian majunya, namun tidak dapat dipungkiri masyarakat Indonesia masih memberikan kepercayaan kepada praktik pengobatan tradisional seperti pijat, totok, dan jenis praktik pengobatan tradisional lainnya disamping praktik Pengobatan medis resmi dalam memenuhi kebutuhan kesehatannya.Resiko medis seperti malpraktik bisa saja terjadi dalam praktik pengobatan tradisional, walaupun praktik pengobatan tradisional sudah memiliki izin resmi dari Pemerintah, terlebih lagi apabila resiko medis tersebut terjadi pada praktik pengobatan tradisional yang tidak mempunyai izin resmi dari Pemerintah jelas sangat merugikan Pasien.

Pemerintah secara tegas membuat regulasi tentang praktik pengobatan tradisional. Tujuan regulasi tersebut agar Pemerintah bisa mengontrol jalannya praktik pengobatan tradisional, miningkatkan mutu pelayanan dan memberikan kepastian hukum, sehingga masyarakat yang menggunakan jasa pengobatan tradisional terjamin hak-haknya, sebab praktik pengobatan tradisional lebih sering ditangani oleh Pengobat Tradisional yang bukan merupakan tenaga medis yang memiliki kemampuan berdasarkan pendidikan keilmuan yang dimilikinya.

Praktik pengobatan tradisional secara tidak langsung adalah bentuk praktik bisnis. Setiap langkah bisnis yang dilakukan oleh para pelaku bisnis, pada dasarnya 
adalah merupakan langkah hukum, yang notabene berada pada ranah hukum kontrak. ${ }^{1}$ Hakikat hukum kontrak pada dasarnya untuk memenuhi kebutuhan hukum pelaku bisnis, dalam arti tidak sekadar mengatur namun lebih dari itu memberi keleluasaan dan kebebasan sepenuhnya kepada pelaku bisnis untuk menentukan apa yang menjadi kebutuhan mereka. ${ }^{2}$ Sehingga pada dasarnya dalam praktik pengobatan tradisional terdapat hubungan hukum antara Pengobat Tradisional dan Pasien.

Dikaitkan dengan uraian yang dijelaskan diatas, terdapat bentuk hubungan hukum antara Pasien dengan Pengobat Tradisional dalam Praktik Pengobatan Tradisional, adapun dasar gugatan yang dapat digunakan oleh Pasien yang mengalami malpraktik oleh Pengobat Tradisional.

\section{Hubungan Hukum Antara Pasien Dengan Pengobat Tradisional Dalam Praktik Pengobatan Tradisional}

Menurut Keputusan Menteri Kesehatan Republik indonesi nomor: 1076/ MENKES/SK/VII/2003 tentang Penyelenggaraan Pengobatan tradisional, pengobat tradisional adalah orang yang melakukan pengobatan tradisional (alternatif). Dalam Keputusan Menteri Kesehatan nomor: 1076/MENKES/SK/VII/2003 Tentang Penyelenggaraan Pengobatan Tradisional, Pengobat tradisional diklasifikasikan dalam jenis keterampilan, ramuan, pendekatan agama dan supranatural.

Hubungan Pengobat tradisional dengan pasien terdapat 2 (dua) pola hubungan, yakni pola hubungan vertikal dan pola hubungan horizontal yang kontraktual. Dalam hal hubungan vertika, melihat dari sisi kedudukan pengobat tradisional sebagai pemberi jasa pelayanan kesehatan tidak sederajat dengan pasien sebagai pengguna jasa pelayanan kesehatan. Adapun hubungan horizontal kontraktual, kedudukan antara penerima jasa layanan kesehatan dan pemberi jasa layanan kesehatan mempunyai kedudukan yang sama. Pemberi dan penerima layanan kesehatan memiliki hak dan kewajiban masing-masing, sebagai contoh

\footnotetext{
1 Agus Yudha Hernoko, Hukum Perjanjian: Asas Proporsionalitas Dalam Kontrak Komersial (Kencana Prenada Media Group 2014).[97].

${ }^{2}$ Ibid.
} 
pemberi pelayanan kesehatan berkewajiban untuk memberikan informasi terkait metode / cara pengobatan tradisional sesuai dengan keahliannya sedangkan penerima jasa pelayanan kesehatan memiliki hak untuk persetujuan apakah metode tersebut dapat dilakukan oleh pemberi pelayanan jasa kesehatan. Soejono Soekanto mengemukakan pendapatnya yang menyatakan bahwa: ${ }^{3}$

"Hubungan antara dokter dan pasien pada dasarnya merupakan hubungan hukum keperdataan, dimana pasien dating kepada dokter untuk disembuhkan penyakitnya dan dokter berjanji akan berusaha mengobati atau menyembuhkan penyakit pasien tersebut. Hubungan keperdataan merupakan hubungan hukum yang dilakukan oleh pihak-pihak yang berada dalam kedudukan yang sederajat".

Hubungan hukum tersebut diatas merupakan transaksi terapeutik yang didasarkan pada perjanjian. Dalam hal ini yang dituntut bukan perjanjian hasil (Resultaat Verbintenis) atau kepastian adanya kesembuhan atau keberhasilan, melainkan perjanjian tersebut berupa upaya atau usaha (Inspanning Verbintenis) semaksimal mungkin dari dokter dalam upayanya melakukan penyembuhan terhadap pasiennya secara hati-hati dan cermat didasarkan pada ilmu pengetahuan yang layak. ${ }^{4}$

Transaksi terapeutik merupakan kegiatan dalam penyelenggaraan praktik pelayanan kesehatan berupa pemberi pelayanan kesehatan secara invidu yang didasarkan rasa keahlian dan keterampilan, serta ketelitian. Jika dikaitkan dengan pelayanan kesehatan berupa pengobatan tradisional, pengobatan tradisional itu merupakan bagian dari kegiatan upaya kesehatan yang menyangkut sumberdaya kesehatan sebagai pendukung penyelenggaraannya, yang harus tetap dilaksanakan sesuai dengan fungsi dan tanggungjawabnya.

Dengan demikian, hubungan hukum antara pengobat tradisional dengan pasien dapat terjadi karena perjanjian. Perjanjian antara pengobat tradisional dengan pasien ini bersifat timbal balik, dalam arti bahwa perjanjian tersebut akan melahirkan prestasi dari masing masing pihak, dengan lahirnya prestasi / kewajiban yang harus dilakukan masing-masing pihak maka lahirlah hak - hak yang harus

\footnotetext{
3 Soekanto, Soerjono, Pengantar Hukum Kesehatan (Remadja Karya 1983).[4].

4 Komalawati, Veronica, Peranan Informed Consent Dalam Transaksi Terapeutik (PT Citra Aditya Bakti 1997).[30].
} 
diterima oleh para pihak. Dengan demikian maka hubungan hukum yang timbul antara pengobat tradisional dengan pasien dalam pelayanan kesehatan haruslah tunduk pada ketentuan-ketentuan umu perjanjian yang diatu dalam BW.

Bahwa dalam perjanjian teraputik yang terjadi pada pengobatan tradisional ini merupakan perikatan usaha (inspanning verbintenis), perikatan yang didasarkan dari usaha (pemeliharaan, perawatan, pengabdian) guna mencapai suatu tujuan tertentu dalam bidang pengobatan tradisional, bukan merupakan hasil dari perjanjian tersebut dalam hal ini kesembuhan sehatan pasien.

Di dalam Keputusan Menteri Kesehatan nomor: 1076/MENKES/SK/ VII/2003 tentang penyelenggaraan pengobatan tradisional, hubungan hukum antara pengobat tradisional dengan pasien secara eksplisit terkandung dapam Pasal 15 ayat (1) dan (3), dapat ditafsirkan bahwa hubungan hukum antara pengobat tradisional dengan pasien dalam pelayanan kesehatan merupakan hubungan hukum keperdataan yang didasarkan pada kesepakatan parapihak. Pengobat tradisional harus memberikan informasi terkait metode pengobatannya dan pasien diberikan hak persetujuan atas tindakan yang akan dilakukan pengobat tradisional, artinya adalah apa yang dikehendaki oleh pasien, dikehendaki pula oleh pengobat tradisional. Pasien harus percaya dengan metode-metode yang digunakan pengobat tradisional dalam pelayanan kesehatan yang bertujuan untuk penyembuhan pasien, demikian pula pengobat tradisional harus mempercayai keluhan-keluhan yang diutarakan oleh pasien agar pengobat tradisional mengetahui tindakan yang harus dilakukan dalam pelayanan kesehatan yang sesuai dengan kondisi pasien.

Hubungan pengobat tradisional dengan pasien secara yuridis dapat diartikan sebagai kontrak. Kontrak adalah pertemuan pikiran (meeting of minds) dari dua orang mengenai suatu hal (solis). ${ }^{5}$ Dilihat dari segi transaksi terapeutik, pihak pertama dalam hal ini pengobat tradisional adalah pihak yang memberikan pelayanan, sedangkan pihak yang kedua dalam hal ini pasien adalah pihak yang

${ }^{5}$ Guwandi, J, Dokter Pasien dan Hukum (Balai Penerbit FKUI 2003).[19]. 
menerima kontrak pelayanan tersebut. Pasien datang kepada pengobat tradisional sebagai bentuk rasa percaya untuk diberikan suatu pelayanan kesehatan, sedangkan pengobat tradisional menerima kedatangan pasien tersebut dan bersedia untuk memberikan pelayanan kesehatan.

Hubungan Hukum antara pasien dengan pengobat tradisonal merupakan perjanjian terapeutik, dalam hubungan tersebut terdapat hubungan kontraktual,dalam perjanjian tersebut juga harus memenuhi unsur syarat sah perjanjian yang ada dalam pasal 1320 BW, yaitu Kesepakatan para pihak, Kecakapan untuk membuat perikatan, suatu hal tertentu dan kauda yang diperbolehkan.

Kesepakatan para pihak, yang dimaksud adanya kesepakatan adalah tidak adnaya kekhilafan, atau paksaan atau penipuan (Pasal 1321 BW). Dalam transaksi terapeutik, seseorang (calon pasien) yang merasa kesehatannya terdapat gangguan mendatangi tenaga kesahatan dalam hal ini adalah pengobat tradisional. Dengan adanya tindakan tersebut berarti adanya rasa percara dengan pengobat tradisional yang dituju. Pasien yang mendatangi pengobat tradisinal menyampaikan keluhan terhadap penyakit yang diderita, pengobat tradisional harus memberikan informasi yang jelas mengenai metode pengobatan, tindakan pengobatan maupun hal hal yang harus dilakukan pasien untuk mendukung penyembuhan dari pihak pasien. Jika pasien terdapat rasa kecocokan dengan metode pengobatan tradisional yang diberikan maka disini terdapat hak pasien untuk menyatakan persetujuan. Dengan demikian terdapat kesamaan kehendak antara para pihak maka timbullah kesepakatan.

Kecakapan untuk membuat perikatan, maka dapat disimpulkan bahwa, kecakapan bertindak merupakan kewenagan yang umum untuk mengkatkan diri, sedangkan kewengan bertindak merupakan kewenangan yang khusus. Berarti, ketidakwenangan hanya menghalangi seseorang untuk melakukan tindakan hukum tertentu, dan orang yang dinyatakan tidak wenang adalah orang yang secara umum cakap untuk bertindak. ${ }^{6}$

6 Ibid.[160]. 
Suatu hal tertentu, Dalam pasal 1333 BW dinyatakan bahwa suatu perjanjian harus mempunyai sebagai pokok suatu barang yang paling sedikit tertantu jenisnya. Dihubungkan dengan obek dalam teansaksi terapeutik, maka urusan yang dimaksud adalah suatu yang perlu ditangani, yaitu berupa upaya penyembuhan. Upaya penyembuhan tersebut harus dapat dijelaskan karena dalam pelaksanaannya diperlukan kerjasama yang didasarkan oleh sikap saling percaya antara pengobat tradisional dan pasien. Oleh karena upaya penyembuhan yang dilakukan itu harus dapat ditentukan, maka diperlukan adanya standart pelayanan pengobatan tradisional. ${ }^{7}$ Standart pelayanan pengobatan tradisional ini dapat dilihat dari pengobatan tradisional tersebut sudah memiliki izin atau tidak memiliki izin. Pemberian izin ini kewenangan dari pemerntah kota/kabupaten hal ini tercantum dalam pasal 6 huruf d Peraturan Pemerintah Republik Indonesia nomor 103 tahun 2014 tentang pelayanan kesehatan tradisional. Dengan diberikannya izin tersebut pemerintah menganggap bahwa klinik / tenaga pengobatan tradisional tersebut memiliki keahlian dan kompetensi di bidangnya sesuai dengan standar yang sudah diberikan pemerintah.

Kasus yang diperbolehkan, hal ini tidak disebutkan secara tegas dalam Undang-Undang, tetapi dapat ditafsirkan secara contrario menurut pasal 1335 BW dan 1337 BW. Dari pasal yang sudah dijelaskan diatas, jika ditafsirkan secara contrario dengan demikian yang dimaksud dengan sebab yang diperbolehkan adalah sebab yang tidak dilarang oleh Undang-Undang, kesusilaan atau ketertiban umum, sedangkan yang dimaksud dengan sebab adalah tujuannya. Dihubungkan dengan transaksi terapeutik, sebagai contoh tindakan pengugguran kandungan atau aborsi dengan alasan apapun merupakan perjanjian dengan sebab terlarang, sebagai contoh adalah tindakan pengguguran kandungan. Penguguran kandungan dilarang oleh Undang-Undang, penguguran kandungan tersebut diperbolehkan jika alasan untuk melakukan tindakan tersebut sesuai dengan Pasal 75 Undang-Undang nomor 36 tahun 2009 tentang Kesehatan.

7 Ibid.[164]. 


\section{Upaya Hukum Akibat Tindakan Malpraktik Yang Dilakukan Oleh Pengobat Tradisional}

Malpraktik atau malpractice berasal dari kata "mal" yang berarti buruk. Sedang kata "practice" berarti suatu tindakan atau praktik. ${ }^{8}$ Perbuatan malpractice menurut kamus Inggris Horrby dan Black menekankan pada tindakan lalai (negligence, neglost of duty), berbeda jauh dari Couglin yang menekankan pada 3 isi yang terdiri dari perbuatan yang sengaja salah (intention wrong doing), perbuatan menyimpang yang tidak sah menurut hukum (illegal practice), dan perbuatan salah yang tidak etis (unethical practice). ${ }^{9}$

Dalam suatu peristiwa yang mana mengakibatkan kerugian terhadap seseorang, maka sudah tentu merupakan kewajiban dari pihak yang melakukan kesalahan atau kelalaian untuk mengganti kerugian yang timbul. Seseorang korban yang dalam hal ini adalah pasien, dari tindakan tersebut mengalami kerugian baik material maupun moril sehingga adalah hal yang sudah wajar jika mereka yang dirugikan tersebut mendapatkan imbalan berupa ganti rugi dari pihak yang melakukan kesalahan atau kelalaian tersebut. Hal tersebut merupakan perlindungan hukum bagi pasien dalam hal terdapat kerugian dalam pelayanan kesehatan yang dilakukan oleh tenaga kesehatan.

Dalam hukum perdata, terdapat konsep atau pengaturan mengenai perbuatan melanggar hukum. Perbuatan melanggar hukum atau disebut juga dengan onrechmatige daad merupakan perbuatan yang melanggar hukum yang dilakukan oleh seseorang yang karena salahnya telah menimbulkan kerugian bagi orang lain. Perbuatan melanggar hukum adalah suatu bentuk perikatan yang lahir dari undang-undang sebagai akibat dari perbuatan manusia yang melanggar hukum yang diatur dalam Burgerlijk Wetboek (BW) atau Kitab Undang-undang Hukum Perdata. ${ }^{10}$

\footnotetext{
${ }^{8}$ Hendrojono Soewono, Batas Pertangungjawaban Hukum Malpraktik Dokter dalam Transaksi Terapeutik (Srikandi 2007).[12].

9 Hendrik, Etika \& Hukum Kesehatan (Penerbit Buku Kedokteran EGC 2011).[67].

${ }^{10}$ Gunawan Widjaja dan Kartini Muljadi, Seri Hukum Perikatan Perikatan yang Lahir dari Undang-undang (PT. Raja Grafindo Persada 2008).[81].
} 
Berdasarkan Direktori Putusan Mahkamah Agung Republik Indonesia, pada putusan nomor 740/Pdt.G/2010/PN.Sby penerangkan kasus posisi pada pokonya bahwa Tri Diana Widiowati adalah pasien pada klinik/griya terapi pengobatan alternatif stroke, vertigo dan migrain yang dipimpin oleh Agus Suyanto. Pada saat konsultasi, Tri Diana Widyowati menceritakan keluhan yang diderita olehnya kepada Agus Suyanto. Berdasarkan konsultasi tersebut Agus Suyanto memastikan bahwa penyakit yang diderita oleh Tri Diana Widyowati adalah vertigo. Dari hasil komunikasi tersebut dan pemeriksaan yang dilakukan oleh Agus Suyanto, Agus Suyanto memberikan alternatif pengobatan menurut keahliannya kepada Tri Diana Widyowati dengan 2 (dua) alternatif cara pengobatan yaitu pengobatan secara rawat inap atau rawat jalan.Mereka membuat kesepakatan yang dituangkan dalam perjanjian sebanyak 3 (tiga) halaman yang berisikan klausul-klausul kesepakatan,Bahwa setelah menjalankan terapi pengobatan tradisional, Tri Diana Widyowati mengalami kemunduran kesehatan anggota tubuhnya, anggota tubuhnya mengalami 50\% (lima puluh persen) kelumpuhan setelah berobat ke klinik/griya Agus Suyanto. Tri Diana Widyowati berobat ke Rumah Sakit Angkatan Darat (RSPAD) ternyata setelah di diagnosa secara medis ditemukan urat syaraf pada tengkuk leher menuju kepala atau jaringan otak mengalami memar atau pecah akibat dari pemijitan secara berlanjut yang dilakukan oleh Agus Suyanto yang akibatnya anggota tubuh Tri Diana Widyowati mengalami 50\% (lima puluh persen) kelumpuhan.

Pengobat tradisional berkewajiban untuk mematuhi standar pelayanan dan standar prosedur operasional sebagaimana yang sudah ditetapkan dalam UndangUndang nomor 36 tahun 2014 tentang Tenaga Kesehatan dan Keputusan Menteri Kesehatan nomor: 1076/MENKES/SK/VII/2003 tentang Penyelenggaraan Pengobatan Tradisional. Adapun ketentuan mengenai standar profesi tersebut ditetapkan oleh asosiasi pengobatan tradisional yang mengeluarkan rekomendasi atas penerbitan izin praktek pengobatan tradisional yang dikeluarkan oleh pemerintah.

Dikaitkan dengan perjanjian terapeutik, bahwa terdapat hubungan hukum yang terjadi antara Tri Diana Widyowati (selanjutnya disebut sebagai sebagai pasien) dan agus suyanto (selanjutnya disebut sebagai pengobat tradisional). Dalam 
kasus ini perikatan yang timbul dari perjanjian terapeutik merupakan perikatan usaha (inspaningverbentenis), yang merupakan suatu perikatan dimana debitur (pengobat tradisional) berkewajiban dengan suatu usaha (pemeliharaan, perawatan, pengabdian) guna mencapai suatu tujuan tertentu. Kewajiban dari pengobat tradisional bukanlah keharusan adanya hasil kesembuhan dari pasien, melainkan upaya/usaha yang dilakukan oleh Agus Suyanto sebagai pengobat tradisional haruslah sesuai dengan standar profesi. Pengobat tradisional berkewajiban untuk mematuhi standar pelayanan dan standar prosedur operasional sebagaimana yang sudah ditetapkan dalam Undang-Undang nomor 36 tahun 2014 tentang Tenaga Kesehatan dan Keputusan Menteri Kesehatan nomor: 1076/MENKES/SK/VII/2003 tentang Penyelenggaraan Pengobatan Tradisional. Adapun ketentuan mengenai standar profesi tersebut ditetapkan oleh asosiasi pengobatan tradisional yang mengeluarkan rekomendasi atas penerbitan izin praktek pengobatan tradisional yang dikeluarkan oleh pemerintah.

Dalam hal ini, walaupun terdapat perjanjian antara pasien dan pengobat tradisional, namun dalam perjanjian tersebut tidak diatur mengenai akibat dari kelalaian yang disebabkan oleh pengobat tradisional terhadap pasien. Berdasarkan hasil pemeriksaan pasien di Rumah Sakit Angkatan Darat (RSPAD) yang mendiagnosa bahwa ditemukan urat syaraf pada tengkuk leher menuju kepala atau jaringan otak mengalami memar atau pecah akibat dari pemijitan secara berlanjut yang dilakukan oleh pengobat tradisional, yang mengakibatkan pasien mengalami kelumpuhan 50\% anggota tubuh, mengindikasikan adanya tindakan malpraktik yang dilakukan oleh pengobat tradisional terhadap pasien.

Atas tindakannya tersebut, Agus Suyanto selaku pengobat tradisional tidak memenuhi unsur kedua dalam pemberian pelayanan kesehatan berdasarkan Undangundang nomor 36 tahun 2009 tentang Kesehatan, yakni “(2) Keterampilan tersebut secara empiris dapat dipertanggungjawabkan dan diterapkan sesuai dengan norma yang berlaku di masyarakat.", dan dalam hal ini pengobat tradisional tidak dapat mempertanggungjawabkan keterampilannya melalui teknik pemijatan yang telah menyebabkan anggota badan pasien 50\% lumpuh. 
Bertambah buruknya kondisi kesehatan pasien pasca dilakukannya suatu tindakan oleh pengobat tradisional, akan memberikan asumsi bagi pasien bahwa telah terjadi malpraktik atau tindakan kelalaian yang dilakukan oleh pengobat tradisional dan kondisi tersebut pun menjadi dasar bagi pasien untuk mengajukan gugatan terhadap pengobat tradisional tersebut. Dalam hal pasien bermaksud untuk mengajukan gugatan dengan dasar wanprestasi, maka pasien harus membuktikan pengobat tradisional tidak memenuhi kewajibannya yang timbul dari adanya suatu perjanjian (tanggungjawab kontraktual). Pasien akan kesulitan membuktikan dimana letak wanprestasi yang dilakukan oleh pengobat tradisional sekalipun pengobat tradisional sudah menjanjikan bahwa pengobatan yang dilakukan oleh pengobat tradisional kepada pasien akan mendapatkan hasil kesembuhan 100\% dari penyakit yang diderita. Tolak ukur pada kasus ini tidak dapat dilihat dari sisi hasil kesembuhan yang akan didapat oleh pasien, melainkan dari usaha yang dilakukan oleh pengobat tradisional.

Berdasarkan Pasal 58 ayat (1) Undang-Undang nomor 36 tahun 2009 tentang Kesehatan disebutkan bahwaSetiap orang berhak menuntut ganti rugi kepada seseorang, tenaga kesehatan, dan/atau penyelenggara kesehatan yang menimbulkan kerugian akibat kesalahan atau kelalaian dalam pelayanan kesehatan yang diterimanya. Dalam hal ini pasien dapat mengajukan gugatan dengan dasar perbuatan melanggar hukum, pasien harus dapat membuktikan bahwa pengobat tradisional melanggar unsur-unsur yang terdapat 1365 BW, yakni (1) apakah perbuatannya melanggar undang-undang, (2) apakah perbuatannya melanggar hak subjektif orang lain, (3) apakah perbuatannya bertentangan dengan kewajiban hukum si pelaku, (4) apakah perbuatannya bertentangan dengan kesusilaan atau kehati-hatian yang sepatutnya dalam masyarakat.

Bahwa transaksi terapeutik ini termasuk dalam perikatan usaha, dilihat dari sisi pembuktian, Agus Suyanto selaku pengobat tradisional harus membuktikan bahwa ia cukup berusaha untuk mencapai tujuannya (bukan hasilnya, tetapi usaha yang dibebankan). Hal ini berkaitan dengan pembuktian yang harus dibuktikan oleh pasien didalam persidangan. Pihak pengobat tradisional harus membuktikan 
melalui dalil-dalilnya bahwa ia melakukan tindakannya sesuai dengan standar profesi, standar pelayanan dan standar prosedur operasional, sedangkan Pihak pasien harus dapat membuktikan dimana letak tindakan perbuatan melanggar hukum yang dilakukan oleh pengobat tradisional, sekalipun nantinya majelis hakim yang memeriksa perkara lah yang berhak untuk menjatuhkan beban pembuktian kepada para pihak.

Jika pengobat tradisional terbukti melakukan perbuatan melanggar hukum ataupun melakukan malpraktik terhadap pasien, maka pengobat tradisional dapat dipertanggunggugatkan. Bentuk tanggung gugat pengobat tradisional adalah mengganti kerugian materiil akibat perbuatan dari pengobat tradisional yang merugikan pasien. Dari perbuatan melanggar hukum yang dilakukan oleh pengobat tradisional tidak hanya menimbulkan kerugian materiil tetapi dapat menimbulkan kerugian immaterial. Kerugian materiil yaitu kerugian yang nyata-nyata ada yang diderita dan dapat dihitung secara pasti oleh pihak yang dirugikan, sedangkan kerugian immaterial adalah kerugian atas manfaat yang kemungkinan akan diterima oleh pihak yang dirugikan di kemudian hari atau kerugian dari kehilangan keuntungan yang mungkin diterima oleh pihak yang dirugikan dikemudian hari

Adapun bentuk tanggung gugat pengobat tradisional dalam perkara diatas adalah berupa ganti rugi. Bentuk ganti rugi tersebut tidak hanya berbentuk pembayaran sejumlah uang tetapi dapat juga berupa barang/jasa yang sejenis atau setara nilainya atau berupa perawatan kesehatan untuk mengembalikan kondisi pasien. Bentuk ganti rugi tersebut dapat juga dalam bentuk tanggungjawab pengobat tradisional untuk mengobati pasien di tempat pengobatan lain ataupun pengobatan secara medis. Pengobat tradisional bertanggung jawab atas baiaya yang timbul dari pengobatan secara medis, termasuk biaya dokter, biaya rumah sakit maupun biaya obat yang dibutuhkan.

\section{Kesimpulan}

Hubungan hukum antara Pengobat Tradisional dengan Pasien adalah Perjanjian Terapeutik dimana para pihak melakukan transaksi dalam bidang pelayanan jasa 
kesehatan didasarkan kompetensi yang sesuai dengan keahlian dan keterampilan di bidang Pengobatan Tradisional. Dalam perjanjian terapeutik harus memenuhi unsur syarat sahnya perjanjian yang ada dalam Pasal 1320 BW.

Dimana dalam tindakan pengobatan tradisional tersebut terdapat tindakantindakan yang tidak memenuhi standar profesi pengobatan tradisional, sehingga pasien dapat mengajukan gugatan perbuatan melanggar hukum sebagaimana tercantum dalam pasal $1365 \mathrm{BW}$ jo Pasal $1371 \mathrm{BW}$ dan pengobat tradisinal juga bertanggung gugat atas tindakan yang dilakukan melanggar hukum sepanjang gugatan yang dilakukan oleh pasien tersebut terbukti di dalam persidangan sesuai dengan pembuktian yang diatur didalam pasal $1865 \mathrm{BW}$.

Pasien lebih memahami bahwa hubungan hukum antara tenaga kesehatan dalam hal ini pengobat tradisional dengan pasien adalah hubungan hukum perjanjian terapeutik dengan demikian melahirkan aspek hukum Inspanning Verbintenis sehingga objek dari perjanjian tersebut adalah usaha dari pengobat tradisional dengan berusaha semaksmal mungkin menyembukankan pasien dengan keahliannya sehingga bukan suatu janji hasil yang pasti deiterima pasien berupa kesembuhan terhadap penyakitnya (Resultaats Verbintenis).

Dilihat dari putusan-putusan hakim terkit gugatan perbuatan melanggar hukum yang dilakukan tenaga kesehatan dan dilihat pula dari cara membuktikan pengobat tradisional dalam melakukan tindakannya sudah memenuhi pengobatan standar profesi, standar pelayanan dan standar prosedur operasional, gugatan dari pasien yang dirugikan / dilanggar haknya, mayoritas putusan tersebut tidak terbukti karena terkendala dengan sulitnya pembuktian adanya perbuatan melanggar hukum. Dengan demikian diperlukannya peraturan menteri kesehatan terkait standart profesi, standar pelayanan dan standar prosedur untuk pengobatan tradisional secara teknis dan terperinci. Terkait hal tersebut pemerintah juga melakukan pendaftaran terkait standar prosedur pengobatan tradisional khususnya pengobatan tradisional dengan keterampilan agar terdapat keterbukaan informasi terkait standar profesi pengobatan tradisional dan dapat dipahami lebih jelas oleh masyarakat atau pasien. 


\section{Daftar Bacaan}

\section{Buku}

Agus Yudha Hernoko, Hukum Perjanjian: Asas Proporsionalitas Dalam Kontrak Komersial (Kencana Prenada Media Group 2014).

Gunawan Widjaja dan Kartini Muljadi, Seri Hukum Perikatan Perikatan yang Lahir dari Undang-undang (PT. Raja Grafindo Persada 2008).

Guwandi, J, Dokter Pasien dan Hukum (Balai Penerbit FKUI 2003).

Hendrik, Etika \& Hukum Kesehatan (Penerbit Buku Kedokteran EGC 2011).

Hendrojono Soewono, Batas Pertangungjawaban Hukum Malpraktik Dokter dalam Transaksi Terapeutik (Srikandi 2007).

Komalawati, Veronica, Peranan Informed Consent Dalam Transaksi Terapeutik (PT Citra Aditya Bakti 1997).

Soekanto, Soerjono, Pengantar Hukum Kesehatan (Remadja Karya 1983).

\section{Perundang-undangan}

Undang-Undang Dasar Negara Republik Indonesia Tahun 1945.

Burjelijk Wetboek.

Herzien Inlandsch Reglement.

Undang-Undang Republik Indonesia Nomor 36 Tahun 2009 tentang Kesehatan.

Undang Nomor 44 Tahun 2009 tentang Rumah Sakit.

Undang-Undang Republik Indonesia Nomor 36 Tahun 2014 tentang Tenaga Kesehatan.

Undang-Undang nomor 8 tahun 1999 tentang Perlindungan Konsumen.

Undang-Undang Republik Indonesia nomor 29 tahun 2014 tentang Praktik Kedokteran.

Peraturan Pemerintah Republik Indonesia Nomor 103 Tahun 2014 tentang Pelayanan Kesehatan Tradisional.

Keputusan Menteri Kesehatan Republik Indonesia Nomor 1076/MENKES/ 
SK/VII/2003 Tentang Penyelenggaraan Pengobatan Tradisional Menteri Kesehatan Republik Indonesia.

Peraturan Menteri Kesehatan Republik Indonesia Nomor 61 Tahun 2016 Tentang Pelayanan Kesehatan Tradisional Empiris.

\section{Putusan Pengadilan}

Putusan Pengadilan Negeri Surabaya Nomor: 740/Pdt.G/2010/PN.Sby Perihal Gugatan Perbuatan Melangar Hukum Perkara Drs. Tri Diana Widowati, 26 Oktober 2010

HOW TO CITE: Syifa Alam, 'Perlindungan Hukum Bagi Pasien Terhadap Malpraktek Pada Pengobatan Tradisional' (2018) Vol. 1 No. 3 Media Iuris. 